\title{
Comparative Assessment of Geomorphological and Landscape Features Around the Small Aral Sea
}

\author{
Akmaral U. Issayeva', Arystanbek A. Yeshibayev' ${ }^{1}$, Boguslawa M. Leska ${ }^{2}$, \\ Beata Messyasz ${ }^{3}$, Azhar A. Abubakirova ${ }^{4}$, Assel Ye. Tleukeyeva ${ }^{4 *}$ \\ 1 Biology and Ecology Institute, Shymkent University, Karatau region, quarter 225, 426 built, Shymkent, \\ Kazakhstan \\ 2 Adam Mickiewicz University in Poznań, Faculty of Chemistry, Department of Supramolecular Chemistry, \\ Umultowska 89b, 61-614 Poznań, Poland \\ 3 Adam Mickiewicz University in Poznań, Faculty of Biology, Department of Hydrobiology, Umultowska 89, \\ 61-614 Poznań, Poland \\ 4 M. Auezov South Kazakhstan University, Tauke Khan Ave. 5, Shymkent, Kazakhstan \\ * Corresponding author's e-mail: aseltleukeyeva@mail.ru
}

\begin{abstract}
The ecological state of the Aral Sea remains an important issue affecting the overall state of the ecosystem in the region. Despite the fact that the state of the northern part of the sea or the Small Aral Sea can be described as stable, the southern part of the former sea continues to degrade. The area of degraded ecosystems around the Small Aral Sea is significant, and huge salt reserves remain the cause of further degradation of terrestrial ecosystems in the Aral Sea region. This study includes the results of geobotanical investigations researches of the dried bottom around the Small Aral Sea area. Five types of landscape-geomorphological formations of the dried-up sea were identified during the research. The creation of the formations took place during different periods of drying and depended on the element's of sea relief. The vegetation of these landscapes is represented exclusively by salt-tolerant species of xerophytic flora. In this case, the number of plant species in the plant communities of these landscapes is directly proportional to the concentration of salt in the soil.
\end{abstract}

Keywords: ecology, the Aral Sea, salinity, flora, landscape

\section{INTRODUCTION}

The Aral Sea originated in the Turan's lowland about 35,000 years ago and was the fourth largest lake in the world after the Caspian Sea, the Upper Lake (North America) and Lake Victoria (Africa) until its desiccation. It is located in the center of the Central Asian deserts. Its altitude is 53 meters above sea level. Due to its large size, it named a the sea. Originally, the volume of the Aral reached 1,064 cubic kilometers, with 66.4 thousand square kilometers of the water mirror and $426 \mathrm{~km}$ in length. It was $284 \mathrm{~km}$ wide and predominantly 25-35 meters deep with 69 meters at its deepest point. Salinity of water was 8-14 g / 1 [Berg, 1908]. The reservoir served as a giant vaporizer in the deserts and had a huge impact on the weather conditions of the whole region. About 60 cubic kilometers of the Aral water per year used to evaporate and come into the atmosphere [Boomer, 2008]. The sea has contributed to the improvement of the hydrothermal regime of local geosystems as well as significantly affected the water regime of desert plants. It has ensured the productivity of pastures and the normal functioning of artesian wells. Scientists believe that the Aral has disappeared many times in its history and has been refilled again. It is scientifically confirmed that over 100 centuries, there were 9 of such cycles [Chatalova, 2017]. The modern sea is believed to be a remnant from the ancient sea, which used to be connected with 
the Caspian Sea while the latter, in turn, was connected with the Black and Mediterranean seas [Velasco, 2018]. The changes in the Sea volume were caused by natural processes, which occurred in the lithospheric plates of the Earth's crust. The level of evaporation and percolation of water into the ground, the water balance of the rivers flowing into the lake and the amount of precipitation in the region played an important role in the restoration of the lake and in the stability of its condition [Massakbayeva, 2020].

Two transboundary rivers of Central Asia - Amudarya and Syrdarya used to be the main source of replenishment for the Aral's water reserve. In its normal state during the last centuries, the Aral has ensured the stability of the existing ecosystems of the arid zone of Central Asia. These zones were a region with a wide variety of animal and vegetable worlds. The water bodies of the sea were inhabited by 38 species of fish and a number of rare species, for example, the number of saigas reached 1 million heads and the floristic composition was 638 species of higher plants. In addition, the Aral played an important role in the development of the economy of the regions of Uzbekistan, Kazakhstan and Turkmenistan. In particular, the development of the productive sectors ensured employment of the population and the formation of a stable social infrastructure. In the past, the sea was one of the richest fishing grounds in the world. The annual catch of fish in the Aral Sea basins is estimated at 30-35 thousand tons. More than 80 percent of the inhabitants of the Aral Sea coast were engaged in the extraction, processing and transportation of fish and fish products [Aladin, 2004]. Fertile lands of the delta of the Amudarya and Syrdarya, as well as highly productive pastures provided employment for more than 100 thousand people in the sphere of livestock, poultry farming, growing of agricultural crops. However, the excessive use of the waters of the rivers feeding the Aral Sea for economic purposes led to irreversible changes in its water balance. Over the past 60 years, the Aral Sea has practically dried up. Thus, anthropogenic factors have turned it into a zone of ecological catastrophe on a global scale. Nowadays, the negative environmental, climatic, socio-economic as well as humanitarian consequences of the catastrophe are experienced by the Central Asian countries populated by 62 million people [China Focus, 2020].

The process of degradation started in 1918 due to the Soviet government's decision to change the direction of the Amudarya and Syrdarya riverbeds for the purpose of the wide-scale development of agricultural production in the desert zone. The production of cotton and rice was the main priority of the agricultural strategy of the Soviet government [Micklin, 2007]. The disappearance of the Aral Sea was expected; therefore, it can be said that it was planned. However, at that time people could not imagine the scale of the upcoming ecological catastrophe. Large-scale construction of irrigation canals began in the 1940s. Most of the irrigation canals were of poor quality that allowed some water to evaporate or seep. The largest canal of Central Asia, the Karakum River had lost more than $50 \%$ of water as the result of poor actions. Overall, about 40 thousand cubic meters of water annually left for the land instead of the sea. In addition, over the years, the population in the desert region has grown by 14 million people. All these factors led to an increase in the flow of water from the rivers (Fig. 1.) Due to the undermining of water supply, the Aral Sea began to rapidly contract. The latter fact and the irretrievable removal of river water for increased irrigated areas had collapsed the ecological balance. After that, the Aral Sea reached only half of the previously formed river flow; still, even that amount was enough to maintain the sea level. However, the further increase in the agrarian orientation of the development of the economy and the volume of irretrievable water consumption led to irreversible consequences. Signs of irretrievable degradation of the water balance of the Aral Sea began to be observed already in the 1960s. By 1982, the flow of water into the sea had been greatly reduced. It was only 2.28 cubic kilometers [Izhitskiy, 2014]. The sea had departed significantly from its shore, and the bottom of the sea was exposed, covered with salts and a mixture of pesticides and other chemicals coming in together with the drained waters from the fields (Fig. 2).

The process of degradation of the Aral Sea can be divided into three stages: 1- from 1960 to 1980, when water level in the sea fell sharply, the salt concentration increased and the sea was close to dividing into parts; $2-90 \mathrm{~s}$, when the southern and northern parts separated by land formed in the sea; 3 - the first quarter of the 21 th century, when the southern half of the sea was divided into east and west continuing further degradation and the northern half of the sea separating into the Small Aral with a stable state. Thus, during the period from 1960 to 2007, the Aral Sea lost 


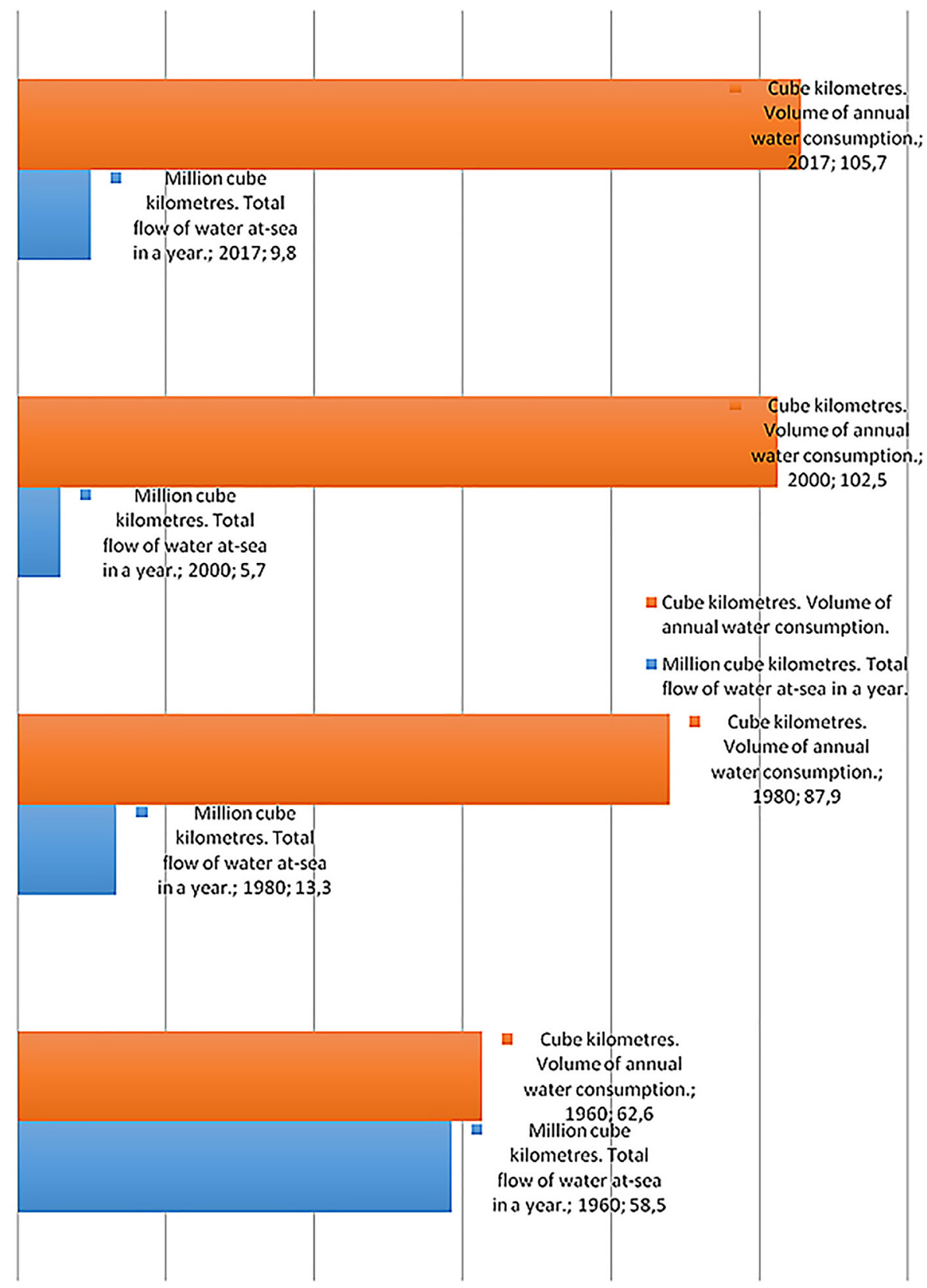

Figure 1. Comparative indicators of annual drainage in the sea and water consumption of the region for the last 57 years.

about $1000 \mathrm{~km}^{3}$ of water due to evaporation [Ziganshina, 2018]. By the early 2000s, the absolute water level in the sea dropped to a level of $31 \mathrm{~m}$, which is $22 \mathrm{~m}$. below the initial level observed in the late 1950s. In 2003 the surface area of the Aral Sea contained about a quarter of the original size, and the volume of water about $10 \%$. Afterwards, the state of the sea began to depend on the amount of precipitation.

Hydrometeorological services of the Central Asian countries, the Aral Sea basin was drier in 2011 in comparison to 2010. The delta of the Amudarya dried up and all three southern segments of the Great Aral Sea (especially the eastern basin) also decreased significantly in size [Aladin, 2020]. Cut off from the Great Aral Sea dam, the Small Aral Sea is more stable, but in 2011 its area also declined compared to 2010. In 2012-2014 there were significant fluctuations in the volume and depth of the sea, depending on the amount of precipitation. However, these temporary fluctuations do not have a significant effect on the recovery process of the sea. At the moment, the state of the sea is stated as a real ecological catastrophe of global scale [Loodin, 2020]. 


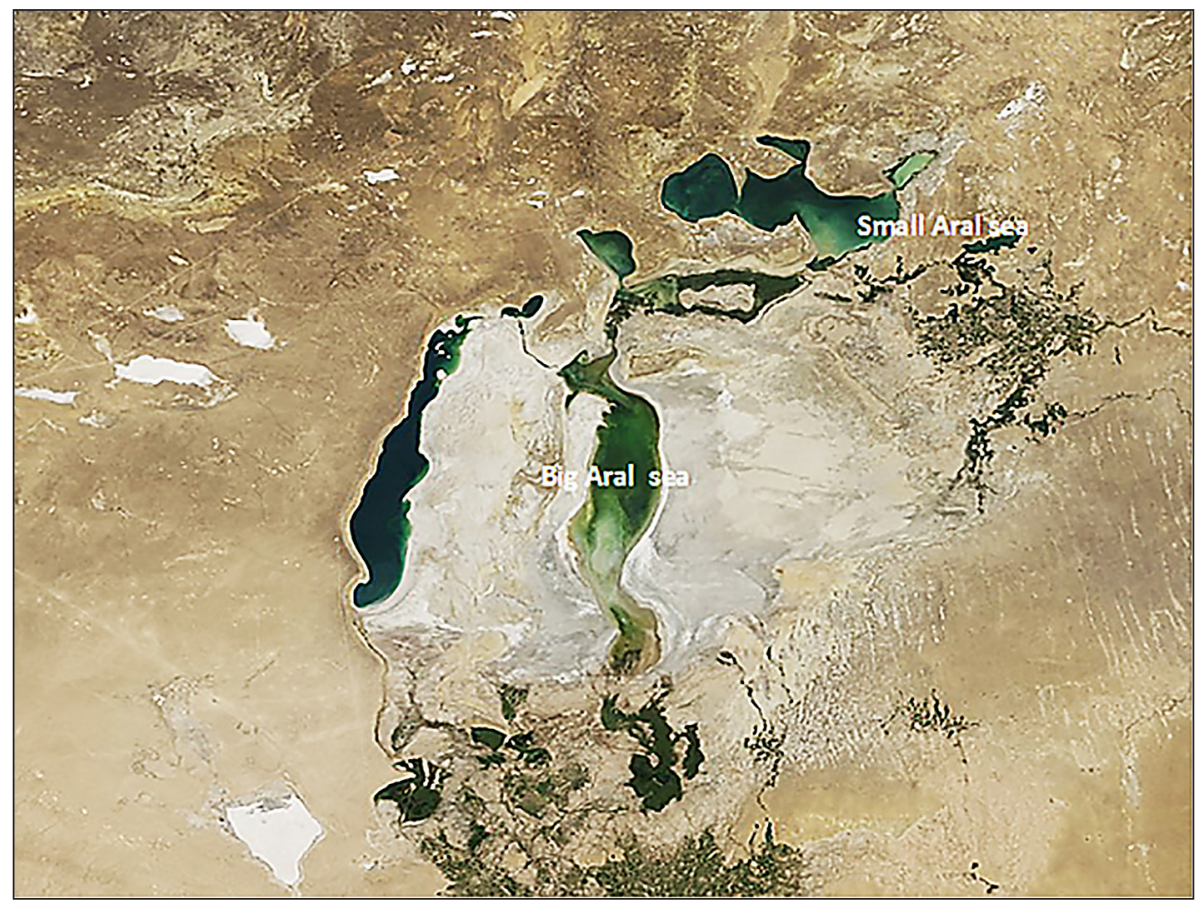

Figure 2. Image of the Great and Small Aral Sea from outer space

The degradation of the Aral Sea has significantly influenced the local climate. According to the data of the hydrometeorological service of the Kyzylorda region, the climate in the Aral Sea became more continental and arid within a radius of $50-100 \mathrm{~km}$ over former water area. In a narrow coastal strip (up to $30 \mathrm{~km}$ from the former shoreline) the winters became 1-3 degrees colder. The bottom of the sea was exposed on an area of 23 thousand square kilometers, and the coastline receded by $60-80$ kilometers. On the bottom of the receding sea was formed the desert Aralkum, composed of sand and salt. Strong winds develop intense dust storms in that area with the dust trail reaching 200-300 km in length, which managed to absorb 2 million hectares of former arable land [ Zavialov, 2010]. Moreover, the dust storms, depending on the direction of the wind, can reach cities such as Kyzylorda, Baikonur and Shalkar. Since salt deposits on a dried bottom contain large amounts of chemical fertilizers and pesticides, inhalation of the local air can adversely affect the health of people and animals in these regions.

Shoaling and separation of different parts of the sea have led to a change in the channels feeding the sea of rivers. Syrdarya now flows only into the Small Aral, which is located in the northern part of the former sea area. The desiccation of the sea led to an increase of salinity in the water, which caused the disappearance of freshwater fish [Krivonogov, 2014]. The length of vegetative season decreased to 170 days. The productivity of pastures has decreased by half, and the loss of floodplain vegetation has reduced the productivity of the floodplain by 10 times. In the coastal areas of the Aral Sea, atmospheric precipitation has decreased several times with the average value of 150-200 $\mathrm{mm}$ and a significant unevenness in the seasons [Cretaux, 2015]. There is a high volatility (up to $1700 \mathrm{~mm}$ per year) and a decrease in air humidity by $10 \%$.

Large area of the Aral Sea is composed of sands and soils of light mechanical composition that are involved in wind erosion. Drying of the Aral Sea caused a double desertification. One was due to the appearance of a drained seabed, whereas; the second resulted the artificial bogging of irrigated land. As a result, a new desert was formedin the center of the belt of great deserts - Aralkum. The effect of pollution is enhanced by the fact that the Aral Sea is located on the highway of a powerful jet stream of air from west to east. This facilitates the transfer of aerosols to the high layers as well as their rapid spread in the atmosphere and ecosystems which are thousands of kilometers away from Central Asia by [Bourdais, 2020].

Possible solutions of the Aral's environmental problem were posed even in the USSR. It was the time when first salt deserts were appearing on the seabed that was a highly dangerous factor; a seabed of Aral Sea has been connected with the"Vozrozhdenie" island, where bacteriological 
weapons were being tested. Three main ways were planned for solving the problem. The first was to increase the flow of water into the Aral Sea by changing the course of some Siberian rivers to the latter [Ermakhanov, 2012]. However, this path was recognized in 1986 as not feasible due to the unsustainable economy of the USSR.

The second way was to solve the problem at the regional level. The international law on the use of water resources of transboundary rivers was developed on this issue, which provides for a common commitment of the states of the region to cooperate in order to achieve the optimal use and protection of an international watercourse [Micklin, 2016]. An important beginning of such cooperation was the meeting of the Heads of Republics of Kazakhstan, Kyrgyzstan, Uzbekistan, Tajikistan and Turkmenistan held in March 1993. The "Agreement on joint actions to address the Aral Sea and the Aral Sea problem, ecological improvement and ensuring social and economic development of the Aral region" was signed at that meeting. In 1992, the Interstate Commission for Water Coordination was established [Micklin, 2014]. Since that time, water consumption and observation of changes in water resources in the Central Asian countries have been the subjects of discussion and agreement by the five countries.

The third way to solve this global environmental problem was created in 1993 founding the International Fund for Saving the Aral Sea (IFAS). Five countries of the region acted as founders of this fund. The main objective of the Foundation was to finance joint practical actions, programs and projects for the environmental improvement of the Aral Sea basin, raising the level of socio-economic status of the region's population. In December 2008, IFAS received the observer status at the UN. The UNECE program "Regional Dialogue and Cooperation on Water Resources Management in Central Asia" provided support in strengthening IFAS. The German Government funded the program through GTZ (Deutsche Gesellschaft für Technische Zusammenarbeit), which is part of the water and environmental component of the European Union Strategy for Central Asia [19]. A Memorandum of Understanding between the United Nations and the Executive Committee of IFAS was signed in Ashgabat. Over the past seven years, about two billion dollars have been spent on the restoration of the Aral Sea [Plotnikov, 2014]. The next target program operated between 2011 and 2015. This is the third program since the creation of the International Fund for Saving the Aral Sea [Sambaev, 2017]. In addition, the measures to save the dying sea continue in the territory of each of the five countries of Central Asia [Micklin, 2016].

As it was said above, at the present time Kazakhstan has the northern part of the Aral Sea-the Small Aral. In order to provide the stability of the existence of the Small Aral in 2005 Kazakhstan built the Kokaral Dam (Figure 3). It separated the Small Aral from the rest. This part of the sea is now in a more stable state. The increase in the runoff volume in the sea and separation of the northern part from the rest significantly increased the water level, as well asreduced evaporation and the salinity of the water. In 2006 the significant increase of the sea level was recorded. Nowadays, the possibilities of further recovering the sea volume and the problem of salinity in the surrounding areas are being explored. The Ministry of Ecology, Education and Science of the Republic of Kazakhstan implements various scientific projects to study the problems of using sea salt, protect agricultural land from further salinization, reduce salt concentration and return saline soils to agricultural production. In this regard, a scientific expedition to the water area of the Small Aral was organized in 2018. The aim of the study was to assess the landscape-geomorphological properties of the dry bottom and the shoreline of the Small Aral Sea and to evaluate the effect of the degree of soil salinity of the coastline on the species diversity of the flora in the zone of ecological disaster.

\section{MATERIAL AND METHODS}

The objects of the study were geomorphological formations, sea salt and flora of the dried sea bottom around the water area of the Small Aral. The studies were conducted in 2018 , at 15 points of the bottom of the former sea (Fig. 3). Types of landscapes on the former sea bottom and species compositions of the halophyte flora were determined. During the investigation, 75 samples of salt, 370 plant samples and 25 soil samples were selected and analyzed. The composition of sea salt was determined by the method of Stationary distillation desalting units [GOST 26449.1-85]. Taxonomic analysis was made on the basis of the results of cameral processing of the herbarium material of the expedition. 


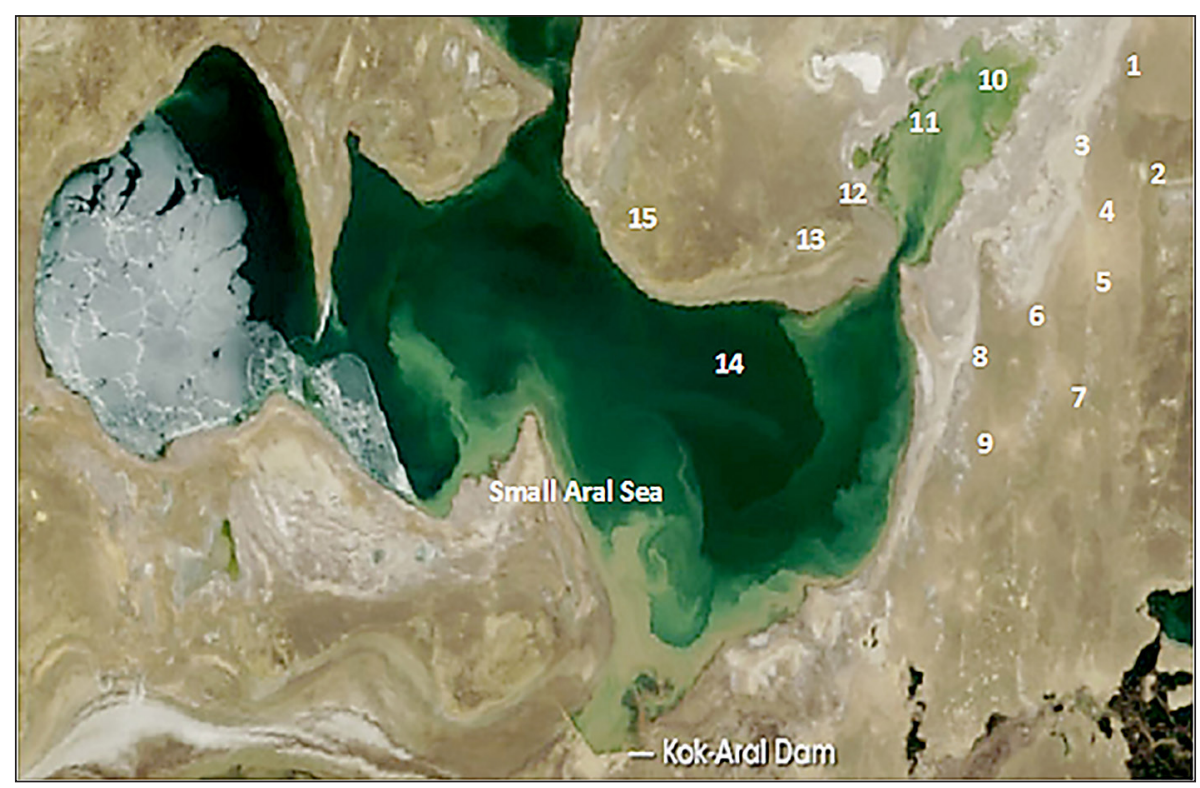

Figure 3. A survey zone of desert landscapes of the dried-up bottom of the Aral Sea (around the Small Aral Sea)

The species composition of the flora was determined using the illustrated determinant "Flora of Kazakhstan in 9 volumes, 1999" [Baitenov, 1999]. The vegetative cover of the soil with vegetation was determined with the method of Vasilevich V.I. [Vasilevich, 1969]. The method of the projective coverage is used for creeping and low-growing herbaceous or shrubby plants, when they form dense curtains. In this case, two values are set: the average projective coverage and the average yield of the raw material with $1 \%$ of the projective coating (price of $1 \%$ coverage). The geomorphological properties of elements of landscapes and their types were determined according to the classification of Rafikov [Rafikov, 1982]. Moreover, the topographic maps of the shoreline were studied and the results of mechanical and mineralogical analyses of the lithological differences in the sea rocks of different years (1960-1990) were analyzed. The main attention was paid to the field of a complex study of the basic properties of landscapes: geological structure, material composition and soil salinity, relief, relief-forming processes, the nature of plant associations. The regularity of the confinement of various relief elements to the quaternary formations of different genesis was revealed, as well as the dependence of the nature of vegetation on the relief, composition of the bottom sediments, and drying time. The geomorphological studies consisted in studying the observed forms of relief, describing their external appearance, establishing their sizes, slopes and dissections, as well as determining their origin and time of formation. Geomorphologic conclusion was made based on the results of those studies.

\section{RESULTS AND DISCUSSION}

It is known that the Aral Sea first approached the city of Aralsk, which is now $80 \mathrm{~km}$ from the water area of Small Aral. The sea retreated for a certain time and at different speeds. In different periods of retreat, the salinity of the sea water was also different. In addition, the bottom relief played a great role in the accumulation of salt. It should be noted that most of the bottom landscape around the Small Aral Sea is formed as a result of rapid sea level retreat and sharply differs from the bottom of the large Aral Sea. In most of the former seabed, the landscape is structurally similar to the native landscape around the sea. Nevertheless, with the retreat of the sea in deeper elements of the sea bottom relief small lakes of different depths were formed. After complete evaporation, these small lakes left large reserves of sea salt, which are still a source of environmental pollution. The results of laboratory analyses have established that sea salts in their chemical composition belong to the chloride group, although deposits of sulfide compounds are also found in some cases (Bishimbayev, 2020). As shown in Table 1, the results of a chemical analysis of 
Table 1. The chemical composition of salts of the solonchaks of the Small Aral Sea (main components)

\begin{tabular}{|c|c|c|}
\hline Elements & \% of mass & $\mu \mathrm{g} / \mathrm{L}$ \\
\hline $\mathrm{B}$ & 0.001039747 & 593.7200 \\
\hline $\mathrm{Mg}$ & 0.046351029 & 63073.6600 \\
\hline $\mathrm{Al}$ & 0.003912761 & 78.0350 \\
\hline $\mathrm{P}$ & 0.005430454 & 203.2210 \\
\hline $\mathrm{K}$ & 0.018169232 & 11514.1000 \\
\hline $\mathrm{Ca}$ & 0.236304506 & 67786.4576 \\
\hline $\mathrm{Ti}$ & 0.000126723 & 5.2341 \\
\hline $\mathrm{Fe}$ & 0.025324563 & 1263.2342 \\
\hline $\mathrm{Cu}$ & 0.002123332 & 2132.5411 \\
\hline $\mathrm{Zn}$ & 0.002343253 & 3.1234 \\
\hline $\mathrm{Ag}$ & 0.000045364 & 2.2534 \\
\hline $\mathrm{Co}$ & 0.000012432 & 0.3243 \\
\hline $\mathrm{Ba}$ & 0.0006243001 & 7.2364 \\
\hline $\mathrm{Cr}$ & 0.0034524321 & 32.4323 \\
\hline $\mathrm{Ni}$ & 0.000254364 & 4.6300 \\
\hline $\mathrm{Mo}$ & 0.0000354231 & 15.6534 \\
\hline $\mathrm{Na} \mathrm{SO}_{4}$ & 1.89 & $1.98 \mathrm{~g} / \mathrm{L}$ \\
\hline $\mathrm{NaCl}$ & 89.98 & $1188.98 \mathrm{~g} / \mathrm{L}$ \\
\hline
\end{tabular}

the salt composition showed that the proportion of sodium chloride in samples from 15 sampling points is $89.98 \%$, and that of sulfates does not exceed $2.0 \%$.

All the results of the above studies were taken into account in identifying the landscapes of the dried bottom of the sea. Thus, considering all the revealed features, five type of landscapes were identified.

The first type of landscape included a part of the coastline and gently sloping belts of the former bottom with sandy soils underlain by loam and sandy loam with a depth of groundwater exceeding 5-7 meters. Such landscapes from the total volume of our studies occupied about $58.5 \pm$ $2.3 \%$ of the area (Fig. 4 ).
This type of landscape is formed in the territories from which the sea water quickly faded. The surface of the soil is covered with a loose layer of dust and salt raised by the process of crystallization of salt during evaporation and the remains of sea shells. The soil is sandy or sandy loam with mechanical composition with chloride type of salinity, the degree of salinity with toxic ions of salts is medium saline $\left(\mathrm{Cl}: \mathrm{SO}^{2-}-0.10-0.30\right)$. In terms of species composition (Table 2) and projective coverage of the soil surface, the vegetation of such areas is much richer compared to the rest of the landscapes (Fig. 5).

However, it is formed only by representatives of long-standing halophyte-xerophyte groups of plants, effectively using the moisture of spring precipitation and groundwater. Moreover, there are some kinds of etimeroid vegetation. By type, this flora belongs to the class of halophytic vegetation Nitrarietea schoberi, with a predominance of perennial halophytic shrubs and semishrubs. All the diversity of vegetation can be combined into two plant associations: Salsolo-Nitrarion schoberi and Halostachio-Nitrarion schoberi. In total, 28 plant species, representatives of the Amarantaceae, Asteraceae, Poaceae, Fabaceae, Zygophyllaceae, Caryohhollaceae, Brassicaceae, Primulaceae, Plumbaginaceae, Plantaginaceae, Cyperaceae, Poligonaceae, Indaceae, and Juncaceae families were identified for this type of landscapes.

In general, the flora of the first type of landscape, in accordance with its specific composition, resembles the flora of the native territory around the sea, although it is highly impoverished in species composition and is characterized by a very low index of projective soil coverage of vegetation, $40.5 \pm 1.7 \%$. Nevertheless, the vegetation

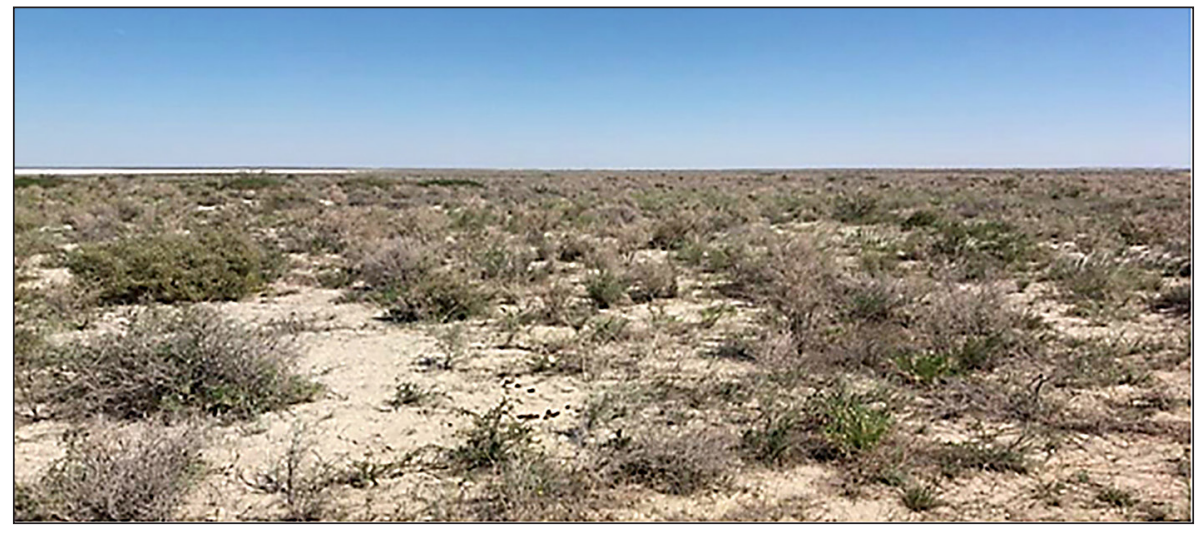

Figure 4. View of the first type of terrain 
Table 2. Species of plants of phytocenosis and their ecological groups in relation to soil salinity

\begin{tabular}{|c|c|c|c|c|c|c|}
\hline Name of species & $\begin{array}{c}\text { I type of } \\
\text { terrain }\end{array}$ & $\begin{array}{c}\text { Il type of } \\
\text { terrain }\end{array}$ & $\begin{array}{c}\text { III type of } \\
\text { terrain }\end{array}$ & $\begin{array}{c}\text { IY type of } \\
\text { terrain }\end{array}$ & $\begin{array}{c}\text { Y type of } \\
\text { terrain }\end{array}$ & Ecological status \\
\hline Tripolium vulgare & yes & no & no & no & no & Crinogalophytes \\
\hline Astragalus brachypus & yes & yes & no & no & no & Crinogalophytes \\
\hline Corispermum laxiflorum & yes & yes & no & no & no & Crinogalophytes \\
\hline Aeluropus littoralis & yes & yes & no & no & no & Crinogalophytes \\
\hline Kochia prostrata & yes & yes & yes & no & no & Crinogalophytes \\
\hline Agropyron fragile & yes & yes & no & no & no & Crinogalophytes \\
\hline Alhagi pseudalhagi & yes & no & no & no & no & Crinogalophytes \\
\hline Ephedra distachya & yes & yes & no & no & no & Crinogalophytes \\
\hline Stipa lessingiana & yes & yes & yes & no & no & Crinogalophytes \\
\hline Calligonum crispatum & yes & yes & yes & no & no & Crinogalophytes \\
\hline Tragopogon rubber & yes & no & no & no & no & Crinogalophytes \\
\hline Megacarpaea megalocarpa & yes & yes & no & no & no & Crinogalophytes \\
\hline Tulipa biflora, & yes & no & no & no & no & Crinogalophytes \\
\hline Scorzonera pusilla & yes & no & no & no & no & Crinogalophytes \\
\hline Juncus compressus & yes & no & no & no & no & Crinogalophytes \\
\hline Anabasis aphylla & yes & yes & yes & yes & no & Eugalophytes \\
\hline Nitraria schoberi & yes & yes & yes & yes & no & Eugalophytes \\
\hline Haloxylon aphyllum & yes & no & no & no & no & Crinogalophytes \\
\hline Climacoptera aralensis & yes & yes & no & no & no & Crinogalophytes \\
\hline Tamarix gallica & yes & yes & no & no & no & Crinogalophytes \\
\hline Peganum harmala & yes & yes & no & no & no & Crinogalophytes \\
\hline Artemisia scopiformis & yes & no & no & no & no & Crinogalophytes \\
\hline Cyperus papyrus & yes & yes & no & no & no & Crinogalophytes \\
\hline Atriplex fominii & yes & yes & no & no & no & Crinogalophytes \\
\hline Plantago maritima & yes & no & no & no & no & Crinogalophytes \\
\hline Glaux maritima & yes & yes & no & no & no & Crinogalophytes \\
\hline Suaeda acuminata & no & yes & yes & yes & no & Eugalophytes \\
\hline Limonium gmelinii & yes & yes & yes & no & no & Crinogalophytes \\
\hline Artemisia lercheana & yes & yes & no & no & no & Crinogalophytes \\
\hline Suaeda crassifolia & no & yes & yes & yes & no & Eugalophytes \\
\hline Limonium vulgare MILL. & yes & yes & no & no & no & Crinogalophytes \\
\hline Scirpus maritimus & yes & yes & yes & yes & no & Eugalophytes \\
\hline Salsola kali & no & yes & yes & yes & no & Eugalophytes \\
\hline Elymus paboanus & yes & yes & no & no & no & Crinogalophytes \\
\hline Kalídium foliátum & yes & yes & yes & no & no & Crinogalophytes \\
\hline Salsola oppositifolia & yes & yes & yes & yes & no & Eugalophytes \\
\hline Zygophyllum fabago & yes & yes & yes & yes & no & Eugalophytes \\
\hline Sarcocornia quienqueflora & no & no & yes & yes & no & Eugalophytes \\
\hline Salicornia europaea & no & no & yes & yes & yes & Eugalophytes \\
\hline
\end{tabular}

Note: These are the dominant families: Amarantaceae, Asteraceae, Poaceae, Fabaceae, Zygophyllaceae, Caryohhollaceae, Brassicaceae, Primulaceae, Plumbaginaceae, Plantaginaceae, Cyperaceae, Poligonaceae, Juncaceae

cover established for this landscape, in authors' opinion, is able to significantly reduce the negative impact of wind erosion.

The second type of landscapes was marked by islets between the low relief elements of the former sea floor. This type is a terrain with soils in the form of meadow sanded salines with an average depth of groundwater. Such landscapes are mainly located not far from the coastline and form slightly elevated elements against the background of lowland solonchaks (Fig. 6).

Their total volume of the territory surveyed by expedition is $12.5 \pm 0.4 \%$. The soil is loose, on the surface of which a thin layer of salt is found, which is formed during the evaporation of moisture. The vegetation of such a landscape is 


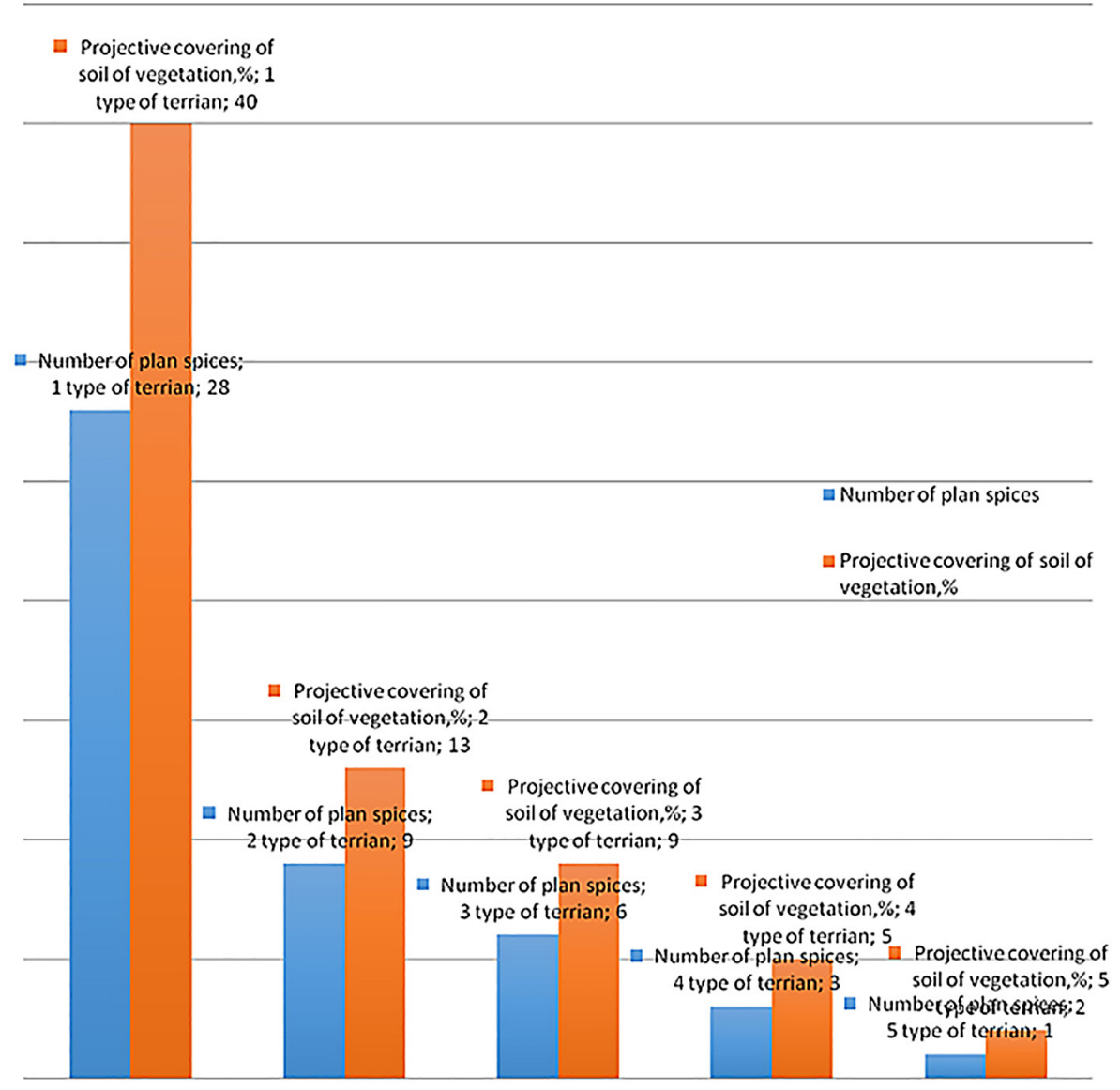

Figure 5. The number of plant species and the projective coverage of soils by vegetation in different landscapes of the dried bottom of the sea

severely degraded. Communities are represented by 9 species of plants, representatives of three families. The established plant species belong to the group highly resistant to toxic salts. The communities of these species provide a projective coverage of the terrain with vegetation of only $11.5 \pm 0.7 \%$, which does not play a significant role against wind erosion.

The third type of landscape occupies $14.6 \pm$ $0.9 \%$ of the investigated area. It covers intermittent salt patches in the sandy soil of the shoreline and the shallow bands of the former bottom, with small reserves of crystallized sea salt (Fig.7). The soil is completely covered with a thin layer of salt, which formed on the surface of a rather large thickness of loose plaster layer, reaching-12-15 cm. Vegetation is completely degraded, and the projective covering of the terrain by plants is no more than $3.9 \pm 0.1 \%$. . Only three types of salt-tolerant plants were established, namely - Sarcocoria quienqueflora, Salsola oppositofolia and Salicornia europaea.
The fourth landscape is formed by soils in the form of sandy saline lands with a low groundwater occurrence, which occupies approximately $9.9 \pm 0.6 \%$ of the area under study. A characteristic feature of this landscape is the completely dry bottom of low reliefs and the presence of a dry mass of sea salt. Deposits of salt have different thickness, depending on the depth of the depressions of the microrelief. There is no liquid brine whatsover. Vegetation occurs in the form of separate specimens or clumps of a single plant species,i.e. - Salicornia europaea (Fig. 8).

The fifth landscape forms the deepest elements of the seabed relief. It is characterized by the presence of a large supply of salt and liquid brine in the center. The presence of a concentrated salt solution is due either to the presence of partially dried lake residues or to the accumulation of surface runoffs of atmospheric precipitation. The thickness of the salt varies depending on the depth of the depressions. Vegetation is completely absent (Fig. 9). 


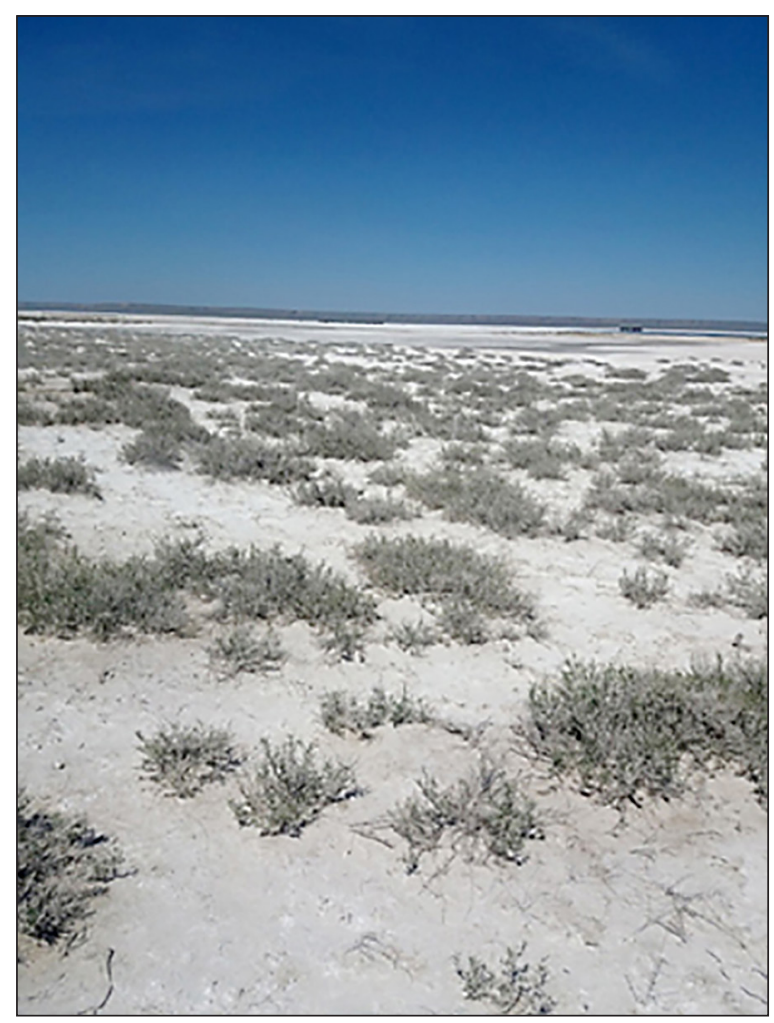

Figure 6. View of the second type of landscape

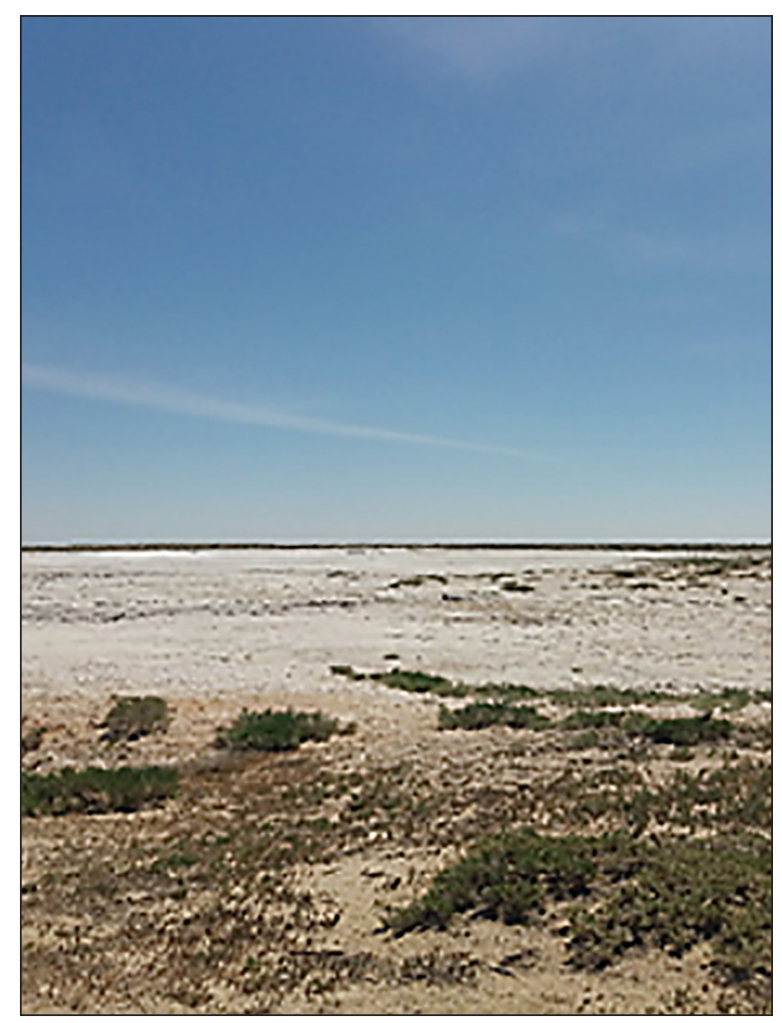

Figure 7. Third type of landscape

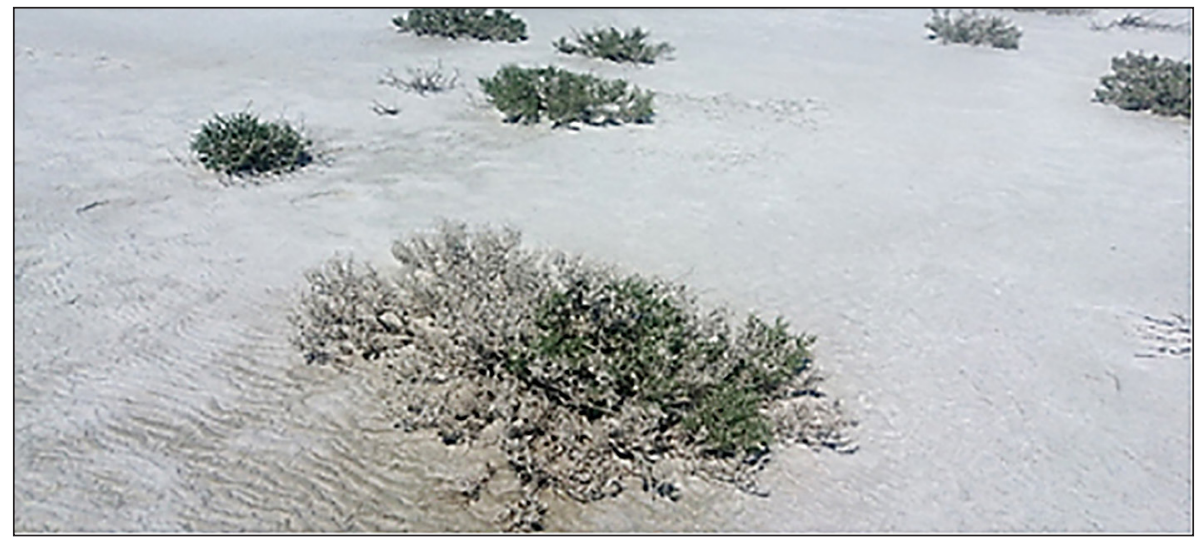

Figure 8. View of the fourth type of the landscape

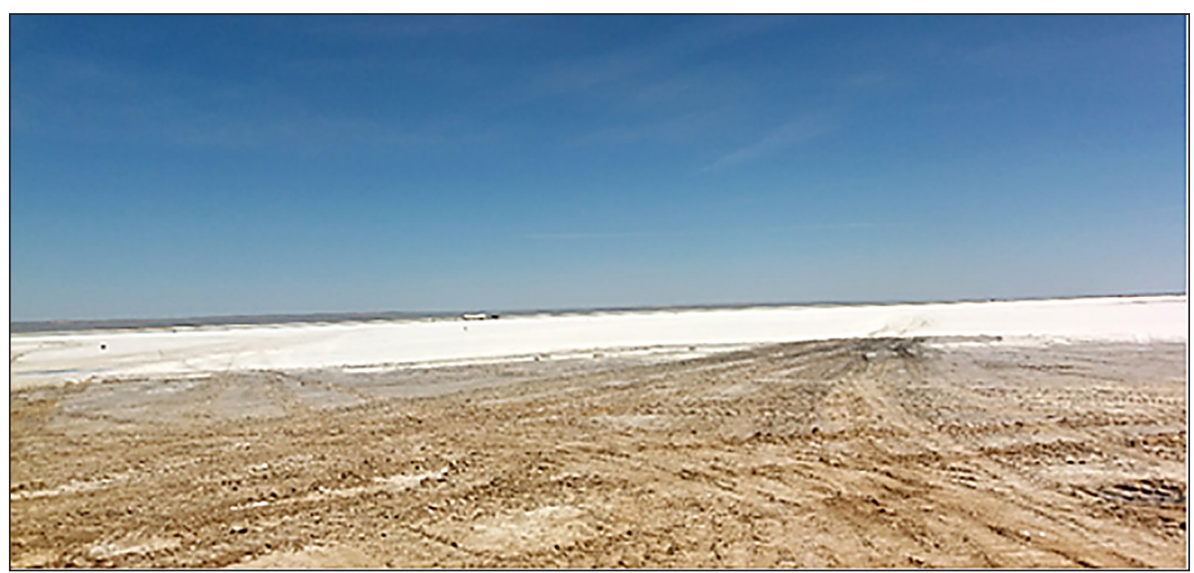

Figure 9. View of the fifth type of landscape 


\section{CONCLUSIONS}

Nowadays, the Aral Sea has retained just 10\% from its former volume. The southern part of the former sea continues to degrade. The state of the northern part of the sea or the Small Aral can be characterized as stable. The sea level gradually increases from year to year, while reducing the level of salinity of water. Nevertheless, the area of degraded ecosystems around the water area of the Small Aral is also substantial. Large salt reserves remain the cause of further degradation of terrestrial ecosystems in the Aral Sea region.

An analysis of the results of the performed studies makes it possible to identify five types of landscape. These geomorphological formations on the bottom of the dried-up sea were formed during different periods of drying of the sea and depending on the elements of the seabed relief. The vegetation of these landscapes is represented exclusively by salt-tolerant species of xerophytic flora. In this case, the number of plant species in the plant communities of these landscapes is directly proportional to the concentration of salt in the soil. In this regard, it should be noted that the study of the Aral Sea region of the dried-up bottom of the sea and the Aral itself should have a multidisciplinary character that would allow each part of the ecosystem to be thoroughly studied: hydrogeology, soil, vegetation, and animal life, and then integrate them, determining their mutual influence on each other.

\section{REFERENCES}

1. Aladin N.V., Høeg J.T., Plotnikov I. 2020. Small Aral Sea brings hope for Lake Balkhash. Science, 370(6522), 1283. DOI: 10.1126/science.abf6682

2. Aladin N.V., Plotnikov I., Letolle R. 2004. Hydrobiology of the Aral Sea. Dying and Dead Seas: Climatic vs. Antropic causes. NATO Science Series IV: Earth and Environmental Sciences. Kluwer, 36.

3. Berg L. 1908. Aral Sea. Saint-Petesrburg, 580. (in Russian)

4. Boomer I., Wunnemann B., Mackay A.W., Austin P, Sorrel P., Reinhardt C., Keyser D., Guichard F., Fontugne M. 2008. Advances in understanding the late Holocene history of the Aral Sea region. Quaternary International, 194(1-2), 79-90.

5. Bourdais P.J, Adibayeva A., Saari D. 2020. Contestation and Collaboration for Water Resources: Comparing the Emerging Regional Water Governance of the Aral Sea, Irtysh River, and Mekong River. Journal of Asian and African Studies. September, DOI: $10.1177 / 0021909620957689$

6. Chatalova L., Djanibekov N., Gagalyuk T., Valentinov V. 2017. The paradox of water management projects in Central Asia: An institutionalist perspective. Water, 9(4), 2073-4441.

7. China Focus. Chinese experience saving Aral Sea. Xinhua, 1 November. Available at: http://www. xinhuanet.com/english/2019-11/01/c_138519091. htm (accessed 1 March 2020).

8. Cretaux J.-F., Biancamaria S., Arsen A., BergéNguyen M., Becker M. 2015. Global surveys of reservoirs and lakes from satellites and regional application to the Syrdarya river basin, Environmental Research Letter, 10(1), AN: 015002, DOI: 10.1088/ 1748-9326/10/1/015002.

9. Ermakhanov Z.K., Plotnikov I.S., Aladin N.V., Micklin P. 2012. Changes in the Aral Sea Ichthyofauna and Fishery During thePeriod of Ecological Crisis. Lakes \& Reservoirs: Research and Management, 17, 3-9,

10. Baitenov M.S. 1999. Illustrated determinant of flora of Kazakhstan. Almaty. Galym. 9(1) (in Russian)

11. Izhitskiy A.S., Zavialov P.O., Roget E., Huang H.P., Kurbaniyazov A.K. 2014. On thermohaline structure and circulation of the Western Large Aral Sea from 2009 to 2011: Observations and modeling. J. Marine. Syst. 129, 234-247.

12. Krivonogov S.K., Burr G.S., Kuzmin Y.V., Gusskov S.A., Kurmanbaev R.K., Kenshinbay T.I., Voyakin D.A. 2014. The fluctuating Aral Sea: A multidisciplinary-based history of the last two thousand years. Gondwana. Res., 26(1), 284-300,

13. Loodin N. 2020. Aral Sea: an environmental disaster in twentieth century in Central Asia. Model. Earth Syst. Environ. 6, 2495-2503. DOI: 10.1007/ s40808-020-00837-3

14. Massakbayeva A., Abuduwaili J., Bissenbayeva S., Issina B., Smanov Z. 2020. Water balance of the Small Aral Sea. Environmental Earth Sciences, 3. DOI: $10.1007 / \mathrm{s} 12665-019-8739-5$

15. Methods of saline water chemical analysis GOST 26449.1-85

16. Micklin P. 2016. The Future Aral Sea: hope and despair. Environmental Earth Science, 75(9), 1-15. http://link.springer.com/article/10.1007/ s12665-016-5614-5

17. Micklin P. 2014. Efforts to Revive the AralSea. In: Micklin, P., Aladin, N.V., Plotnikov, I. (Eds.) The Devastation and Partial Rehabilitation of a Great Lake Series: Springer Earth System Sciences. Vol. 10178, Part III, Chapter 15, 361-379,

18. Micklin P. 2016. The future Aral Sea: hope and despair. Environmental Earth Sciences, 75(9), 2016. 
DOI: $10.1007 / \mathrm{s} 12665-016-5614-5$

19. Plotnikov I.S., Aladin N.V., Ermakhanov Z.K., Zhakova L.V. 2014. Biological Dynamics of the Aral Sea Before Its Modern Decline (1900-1960). In: Micklin, P., Aladin, N.V. \& Plotnikov, I (Eds.) The Aral Sea. The Devastation and Partial Rehabilitation of a Great Lake Series: Springer Earth System Sciences, Vol. 10178, Part I, Chapter 3, 41-76.

20. Rafikov A.A. Uzbekistan and Kazakhstan. Aral Sea. Publisher. Fan. Uzbek SSR, 146, 1982. (in Russian)

21. Sambaev Ns. 2017. The current hydroecological state of the lower reaches of the Syr Darya and the use of its runoff resources. Bull Ecol Educ, 2(40), 50-55. (in Russian)

22. Micklin P. 2007. The Aral Sea disaster. Annual Review of Earth and Planetary Sciences, 35, 47-72.

23. Vasilevich V.I. 1969. Statistical methods in geobotany. Science, 232. (in Russian)

24. Velasco J., Gutiérrez-Cánovas C., Botella-Cruz M., Sánchez-Fernández D., Arribas P., Carbonell J.A., Millán A., Pallarés S. 2018. Effects of salinity changes on aquatic organisms in a multiple stressor context. Philosophical transactions of the Royal Society of London. Series B, Biological sciences, 374(1764). DOI: 10.1098/rstb.2018.0011

25. Zavialov P.O. 2010. Physical Oceanography of the Large Aral Sea. In: Kostianoy A.G. \& Kosarev A.N. (Eds.) The Handbook of Environmental Chemistry The Aral Sea Environment Springer: Germany, 7, 123-146,

26. Ziganshina Dr. 2018. Transboundary environmental assessment in the Aral Sea basin: The interplay of international and domestic law. Central Asian Journal of Water Research, 4(2), 27-47, 